\title{
Resepsi Milenial Pengguna TikTok terhadap Citra Diri Artis (Studi Kasus pada Perseteruan antara Denise Chariesta dan Uya Kuya di Media Sosial TikTok)
}

\author{
Sonia Gandi ${ }^{1}$, Moehammad Gafar Yoedtadi ${ }^{2 *}$ \\ ${ }^{1}$ Fakultas Ilmu Komunikasi, Universitas Tarumanagara, Jakarta \\ Email: sonia.915180149@stu.untar.ac.id \\ ${ }^{2}$ Fakultas Ilmu Komunikasi, Universitas Tarumanagara, Jakarta* \\ Email: gafary@fikom.untar.ac.id
}

\begin{abstract}
Social media is a new breakthrough in communication technology field that wascreated as a simulation of a social environment where people can interact like interactions in the real world. The millennial generation is considered capable of sorting and criticizing the messages they consume on Tiktok social media, especially related to the feud between Denise Chariesta and Uya Kuya. This study purpose to analyze and find out above millennial receptions understand and interpret the artist's self-image on Tiktok social media. With a descriptive qualitative method, the informants interviewed were millennials who followed the Tiktok accounts of the two artists and followed the development of the feud case. The results showed that the millennial understanding to self-image artists Denise Chariesta and Uya Kuya was considered negative and excessive. Millennials' meaning of artist self-image is interpreted in terms of Dominant-Hegemonic Reading, Negotiated Reading and Oppositional Reading. Accepting dominant meanings related to natural feuds, but rejecting the attitudes and traits shown by each artist to the public because they are negative.
\end{abstract}

Keywords: millennial generation, self-image, TikTok

\begin{abstract}
Abstrak
Media sosial merupakan terobosan baru dalam bidang teknologi komunikasi yangdiciptakan sebagai simulasi lingkungan sosial dimana orang-orang dapat berinteraksilayaknya interaksi di dunia nyata. Generasi millenial dinilai mampu memilah dan mengkritisi pesan yang mereka konsumsi di media social Tiktok, terutama terkait dengan perseteruan antara Denise Chariesta dan Uya Kuya. Penelitian ini bertujuan menganalisis dan mengetahui bagaimana resepsi millenial dalam memahami dan memaknai citra diri artis di media sosial Tiktok. Dengan metode kualitatif deskriptif, informan yang diwawancarai adalah millenial yang memfollow akun Tiktok kedua artis dan mengikuti perkembangan kasus perseteruan tersebut. Hasil penelitian diperoleh bahwa pemahaman millenial terhadap citra diri artis Denise Chariesta dan Uya Kuya dinilai negatif dan berlebihan. Pemaknaan millenial terhadap citra diri artis dimaknai secara Dominant-Hegemonic Reading, Negotiated Reading dan Oppositional Reading. Menerima pemaknaan secara dominan terkait perseteruan yang alami, namun menolak sikap dan sifat yang ditunjukan masing-masing artis kepada publik karena bersifat negatif.
\end{abstract}

Kata kunci: citra diri, generasi milenial, TikTok

\section{Pendahuluan}

Media sosial merupakan terobosan baru dalam bidang teknologi komunikasi 
yang diciptakan sebagai simulasi lingkungan sosial dimana orang- orang dapat saling berinteraksi satu sama lain layaknya interaksi di dunia nyata. Bedanya, media ini menjembatani komunikasi melalui jaringan sehingga orang-orang tidak perlu bertemu dan bertatapan langsung untuk sekadar berbagi informasi. Saat ini memanfaatkan media sosial adalah cara untuk berkomunikasidengan orang lain tanpa terikat oleh batas ruang dan waktu.

Media sosial tidak hanya mendukung fungsi komunikasi antarindividu, tetapi juga memberikan kemudahan dalam menerima berbagai informasi dan berbagi berita terkini dari masyarakat sebagai media sharing, menaikkan status sosial, bahkan dapat menunjukkan eksistensi diri. Beragam fungsi inilah yang menarik minat masyarakat untuk masuk ke dalam dunia sosial virtual.

Saat ini, media sosial baru yang tengah naik daun adalah Tiktok. Aplikasiini merupakan jejaring sosial dan platform video musikal yang di berasal dari Tiongkok pada tahun 2016. Beberapa waktu lalu di akhir Mei 2021, perseteruan antara selebgram Denise Charista dengan Uya Kuya yang berawal dari sentilan-sentilan di postingan Tiktok menjalar hingga menjadi sorotan di media televisi. Mereka berdua akhirnya diundang dan dipertemukan dalam acara Pagi-Pagi Ambyar di salah satu stasiun televisi swasta untuk menjelaskan duduk perkara permasalahan tersebut dan kemungkinan menemukan solusi dari permasalahan mereka untuk saling berbaikan. Perseteruan berlanjut dengan sindir menyindir di Tiktok, Denise menyerang keluarga Uya dengan menyebut mereka hanya memiliki 'mobil butut', badan anak Uya bau bawang dan sebagainya.

Dampak dari perseteruan ini tentunya dapat berefek terhadap audience karena posisi mereka sebagai publik figure dengan jumlah followers yang banyak dan populer di media, baik media sosial ataupun media lainnya. Melalui pendekatan reception analysis, penelitian mengkaji pada penelitian ini secara lebih dalam, mengenai proses aktualisasi dari sebuah wacana pada media sosial maupun lainya melalui adanya suatu praktek dan budaya yang terjadi di masyarakat. Generasi millenial dalam posisi ini berperan sebagai penerima pesan terkait perseteruan artis di media sosial Tiktok, yang juga berperan aktif melakukan interpretasi dan kritisi terhadap pesan tersebut ke dalam aspek kognitif, afektif dan behavioral mereka.

Menurut Stuart Hall (1986: 129-138), resepsi adalah bagaimana proses pendekodean audience/penonton terhadap pesan media melalui tiga sudut pandang. Berdasarkan perspektif tersebut, generasi millennial dinilai mampu memilah dan mengkritisi berbagai pesan yang mereka konsumsi di media sosial Tiktok terkait dengan perseteruan antara DeniseChariesta dan Uya Kuya tersebut. Sebaliknya, artis sangat memahami peran citra diri dalam perkembangan karirnya sebagai kelompok yang terkait dengan penggunaan media massa. Semakin banyak sorotan media kepada mereka, semakin tinggi pula popularitas artis tersebut. Terlepas dari hal tersebut, segala informasi yang disampaikan oleh media terkait artis dapat membentuk, mempertahankan atau mendefinisikan citra (Pattipeilohy, 2015: 23).

\section{Metode Penelitian}

Penelitian ini menggunakan metode kualitatif dengan pendekatan deskriptif. Peneliti dibutuhkan sebagai master key karena teknik penelitian kualitatif digunakan untuk mempelajari objek-objek alami dan tak terukur (Sugiyono, 2014:1). Peneliti secara induktif melakukan metode akuisisi data, triangulasi, dan analisis data yang digunakan. Temuan menggunakan pendekatan kualitatif menekankan pentingnya apa 
yang terjadi dalam studi kasus lapangan, daripada menggeneralisasi hasil. Cara ini digunakan untuk mendapatkan hasil yang lebih mendalam dan bermakna (Sugiyono 2014: 3).

Peneliti menggunakan metode deskriptif untuk menggambarkan apa yang diteliti kemudian dan dikategorikan sehingga dapat ditarik satu kesimpulan. Menurut Bungin (2015:4), penelitian deskriptif adalah studi tentang menggambarkan, meringkas, dan merangkum berbagai situasi atau variabel yang terjadi di masyarakat yang menyajikan suatu masalah, dan kemudian membawanya ke permukaan sebagai ciri atau karakteristik kondisi, situasi, atau variabel tertentu. Hasil penelitian deskriptif adalah jenis datayang diungkapkan dalam bentuk kata, frasa, dan uraianuraian (Bungin, 2015:4).Berdasarkan pengertian diatas, maka peneliti berspekulasi bahwa penelitian yang sedang berlangsung adalah penelitian yang sedang dipelajari atau diproses untuk memecahkan masalah yang sedang berlangsung relevan saat memberikan ulasan.

\section{Hasil Temuan dan Diskusi}

TikTok adalah aplikasi China yang baru dirilis di Indonesia pada akhir tahun 2017. Menurut Direktur Pemasaran TikTok, Viv Gong, Indonesia menempati urutan ke enam di antara pengguna Internet di seluruh dunia. Hal inilah yang menjadi dasar aplikasi TikTok saat masuk ke Indonesia. TikTok adalah aplikasi dari ByteDance, sebuah perusahaan teknologi kecerdasan buatanChina yang dikenal di seluruh dunia untuk menyebarkan informasi melalui media dan produk elektronik. TikTok sendiri dapat didownload oleh pengguna dari aplikasi Google Play Android dan App Store (Kompas, 2021).

Secara global, aplikasi TikTok telah didownload lebih dari 500 juta kali, memiliki 10 miliar penayangan video dan 150 juta pengguna setiap hari, dengan Amerika Serikat dan Inggris sebagai pemberi kontribusi terbesar. TikTok adalah media sosial baru yang menyediakan platform bagi pengguna untuk mengekspresikan bakat mereka melalui konten video. TikTok mengubah ponsel Anda menjadi studio yang berjalan. Aplikasi ini berdurasi sekitar 15 detik dan memiliki efek khusus yang menarik dan mudah digunakan yang memudahkan siapa saja untuk membuat video keren. Ada efek khusus seperti video goyang dan efek getaran oleh musik elektronik, perubahan warna rambut, stiker 3D dan sebagainya. Selain itu, pembuat konten dapat mengekspresikan bakat mereka tanpa batas hanya dengan mengakses perpustakaan musik TikTok yang luas (Kompas, 2021).

\section{Kronologis Perseteruan Denise Chariesta dan Uya Kuya:}

Denise Chariesta, selebgram sekaligus pengusaha bunga menjadi pusat perhatian karena perseteruannya dengan Uya Kuya. Kronologisnya, semua diawali dari endorse bunga Dennise kepada anak Uya, Nino Kuya. Perseteruan kemudian berkembang, dari awalnya hanya permasalahan antara Dennis dan Nino Kuya, akhirnya malah merembes ke seluruh keluarga Uya,termasuk istri dan anak-anaknya yang lain.

1. Denise meng-endorse Nino Kuya

Perseteruan diawali dengan Denise yang ingin Nino Kuya meng-endorse brand bunganya. Dennis mengatakan di Instagram bahwa dia merangkaibunga itu sendiri. Buket yang dia rangkai bernilai 60 juta rupiah. Jarak rumah mereka juga cukup jauh, namun Denise yang mengantarkannya sendiri. SetelahNino 
menyetujui buket Denise, ternyata Nino bahkan menerima endorse bunga dari merek lainnya.

2. Denise tak menerima

Dennise marah dengan apa yang telah terjadi dan mengaku tidak dapat menerima hal itu. Ia mengungkapkan masalah ini melalui posting Instagram. "Minggu lalu gue endorse karangan bunga 60 juta ke Nino (putra Uya). Menurut loe bunga gue murah? Bunga mana yang murah, semuanya mahal. Kata Denise dalam video di akun Instagram yang dikutip Minggu, 30 Mei 2021. Denise merasa dirugikan dengan meng-endorse Nino jika sikapnya seperti itu. "Ngapain gue endorse dia, padahal harusnya dia tahu diri, tapi sayangnya tidak. Harusnya dia promote toko bunga gue, ya bunga gue aja". "Selain buang-buang duit gue, buang-buang tenaga gue".

3. Denise ejek mobil Astrid 'butut' dan Cinta berbau bawang

Karena frustasi, Denise kemudian menyerang anggota keluarga Uya yanglain untuk meluapkan amarah. Dia mengejek mobil Astrid yang sudah tua, dan badan Cinta Kuya berbau bawang. Kali ini, Uya Kuya merasa wanita itu sudah keterlaluan, lalu mendatangi rumah Denise. Denise juga sempat mengingatkan Cinta untuk memakai deodoran secara rutin sebelum menggunakan pakaian bergambar anime, dengan harapan ketiak Cinta tidak berbau bawang saat berpakaian.

4. Diduga hanya rekayasa belakang

Netizen pun menduga semua yang dilakukan Denise Charista dan Uya Kuya hanya rekayasa. Uya tidak setuju dengan anggapan tersebut. Dia dengan bangga menyebut dirinya Raja Settingan. "Dibilang raja settingan yes, hanya orang pintar yang bisa menyetting sesuatu, bisa merencanakan sesuatu sehinggasukses dan berhasil," kata Uya.

\section{Pemahaman Millenial Terhadap Citra Diri Artis yangDitampilkan di Media Sosial Tiktok}

Manusia menafsirkan apa yang dia amati, pemaknaan merupakan stimulus dari pengalamannya. Resepsi atau pandangan bersifat positif ketika persepsi individu dipenuhi dengan rangsangan untuk informasi yang relevan.Dalam hal ini, resepsi adalah tentang persepsi informan terhadap konten kontroversial di media sosial Tiktok antara Denise dan Uya Kuya. Proses resepsi pesan meliputi unsur-unsur pesan, komunikan dan komunikatornya, seperti halnya disebutkan pada reception teory Stuart Hall. Proses decoding-encoding antara komunikator dengan komunikan belum tentu berjalan sesuaikeinginan. Pada kasus perseteruan artis di media sosial Tiktok ini, terdapat beberapa tahapan yang dilakukan, yaitu:

1. Proses produksi wacana dan penyampaian pesan

Konten Tiktok yang tersajikan kepada para followers, yang kemudian juga diangkat untuk ditampilkan di Tv tentunya hadir berdasarkan kepentingan pihak-pihak terkait, yang dalam hal ini diawali dengan komentar Denise terhadap postingan Uya Kuya yang sedang memandikan kucing kesayangannya.

Di satu sisi, Uya Kuya sebagai seorang artis yang memiliki puluhan ribu followers membagikan kegiatan sehari-harinya seperti biasa kepada para followers/pengguna Tiktok. Informan 1 (Sepia) memahami makna dari konten Uya Kuya ini sebagai konten yang sewajarnya ditampilkan seorang artis. 
Konten ini juga tidak mengandung unsur sindiran yang dapat memicu perseteruan karena apa yang ditampilkan Uya hanya proses memandikan kucingnya. Namun kemudian konten tersebut ditanggapi dengan sindiran oleh Denise Chariesta. Tak sampai disitu, mereka akhirnya saling berbalasan melemparkan sindiran di masing-masing akun Tiktoknya. Hal inilah yang menimbulkan keanehan bagi netizen atau followers yang melihat. Keanehan ini menimbulkan tanda tanya besar, yang kemudian disorot oleh media lain seperti tv karena status mereka sebagai influencer.

Dengan viralnya perseteruan ini di media sosial, membentuk sebuah fenomena sosial ditengah masyarakat, dimana pesan yang timbul adalah terjadi perseteruan antara dua artis dengan cara saling menyindir dan membawa-bawa nama keluarga di media sosial. Di sisi lain, makna yang ingindisampaikan oleh kedua artis tersebut adalah pembelaan terhadap kepentingannya masingmasing tanpa memikirkan efeknya terhadap followers/ penonton.

Penonton tidak secara langsung menerima struktur makna dari kontenkonten yang saling menyindir tersebut di media sosial Tiktok. Pada tahap ini eksistensi pengirim pesan tidak lagi terlihat karena bahasa dan visualisasi dalam tayangan menjadi elemen yang sangat mendominasi. Visualisasi yang digunakan pada konten berbalasan tersebut secara langsung menyebutkan pihak yang ingin diserang melalui foto dan tag nama. Terlebih lagi kalimat yang mereka gunakan sangat tidak etis, menimbulkan berbagai reaksi netizen dan masyarakat yang khawatir terhadap efek negatif dari sorotan media terhadap konten artis tersebut. Ketika konten saling sindir ini ditayangkan interpretasi terhadap isinya bisa dipastikan menjadi sangat beragam dan sepenuhnya bergantung pada penonton sebagai penerima pesan.

2. Proses pemaknaan

Tahapan terakhir adalah saat di mana penonton berusaha memaknai isi tayangan dengan membongkar kode-kode dari tayangan yang disaksikan. Sama halnya dengan proses produksi, proses pembongkaran kode ini juga meliputi beberapa proses dan dipengaruhi oleh latar belakang penonton. Status informan sebagai mahasiswa, apakah itu pada tingkat awal atau akhir turut memengaruhi cara mereka menginterpretasikan makna dari konten- konten tersebut.

Informan 2 beranggapan bahwa perseteruan antara Denise dan Uya Kuya ini merupakan settingan, dalam artian mereka merencanakan untuk membuat konten fiktif yang memicu perhatian dan tanda tanya masyarakat. Dengan demikian popularitas mereka akan meningkat sejalan dengan rasa penasaran masyarakat dan media tentang apa yang tengah terjadi diantara mereka. Informan juga mempertimbangkan peningkatan jumlahfollowers/ subscriber dan viewers terhadap konten-konten kontroversial tersebut untuk mendukung argumennya. Karena pada nyatanya mereka akansaling diuntungkan setelah kasus tersebut menjadi headline di berbagai media.

Berdasarkan pemaknaan tersebut, dapat dikatakan bahwa informan sebagai millenial khalayak media bukanlah sekumpulan orang yang pasif. Bukan hanya sebagai pasar yang menjadi sasaran industri media, namun khalayak media aktif yang lebih bijaksana untuk menentukan keputusan mereka dalam mengonsumsi isi media. Pola pemaknaan millenial juga sejalan dengan 5 konsep khalayak aktif yang disebutkan Frank Bioca (Littlejohn, 2014), yaitu adanya selektivitas (selectivity), kegunaan (utilitrianism), kesengajaan (intentionality), keterlibatan (involment), dan tidak mudah 
terpengaruh (imrprervious of influence). Oleh karenanya, semakin sengit perseteruan tersebut, maka citra yang tumbuh di masyarakat terhadap artis tersebut akan semakin buruk.

\section{Pemaknaan Milenial Terhadap Citra Diri Artis yang Ditampilkan Melalui Media Sosial Tiktok}

Pemahaman yang disampaikan informan menunjukkan bagaimana cara informan memaknai teks perseteruan antara Denise Chariesta dan UyaKuya yang disajikan dalam video Tiktok. Dari sudut pandang masing- masing penonton, video perseteruan Denise Chariesta dan Uya Kuya yang disuguhkan media sosial Tiktok memiliki banyak implikasi. Khalayak dipandang sebagai produsen makna (producer of meaning) yang tidak hanya proaktif dalam konsumsi, tetapi sekaligus menciptakan makna dari pesan- pesan yang muncul dari isi media. Stuart Hall (Morissan, 2014) menjelaskanimplikasi dari tiga tipe utama audiens dalam menerima teks media, yaitu:

1. Dominant-Hegemonic Reading

Audiens mengambil makna dari tayangan video Tiktok dan menguraikannya sesuai dengan makna yang dimaksudkan oleh teks media (prefered reading). Penonton sudah memiliki pemahaman yang sama, tidak ada pengulangan pesan, komunikator dan komunikan memiliki pandangan yang sama, dan mereka langsung menerima. Khalayak dominan cenderung bereaksi positif terhadap konten Tiktok. Singkatnya cenderung menerima Tiktok sebagai media sosial yang menyediakan informasi informasi lengkap dan terkini yang sesuai dengan kebutuhan informan. Informan hanya menerima isi teks media, sehingga interpretasi informasi terkait kasus perseteruan Dennise Chariesta dan Uya Kuya sama seperti yang disampaikandi media social TikTok. Seperti yang kita lihat, Tiktok adalah media sosial audiovisual dan media ini terpopuler dis eluruh negara.

Audiens memberikan beberapa pemaknaan, seperti informan 1 (sepia) dapat menerima prefered reading (makna dominan yang diberikan oleh media). Informan 1 (Sepia) mengevaluasi video tentang Tiktok yang merupakan media alternatif yang dapat menginformasikan kepada semua orang yang membutuhkan informasi orang dapat mempelajari segala sesuatu yang tidak mereka ketahui.

Dalam kasus perseteruan antara Dennise Chariesta dan Uya Kuya, Informan 1 (Sepia) menganggap perseteruan antara Dennis Chariesta dan Uya Kuya sebagai masalah yang tidak patut dicontoh, informan menilai bahwa peningkatan citra diri artis pada kasus tersebut tidak meningkatkan satu sama lain, melainkan saling menjatuhkan. Salah satu artis hanya ingin membuat sensasi. Informan 1 (Sepia) menganggap remeh apa yang dihadirkan Tiktok di media sosial. Baginya, apa yang ditampilkan di media sosial Tiktok terlihat secara nyata dengan kejadian yang dilihat.

Demikian pula dengan Informan 2 (Angelica), menganggap bahwa perseteruan antara Denise Chariesta dan Uya Kuya tampaknya settingan, karena masalah biasa yang terus berlanjut dan menjadi kurang penting. Bagi mereka, Tiktok mampu memberikan informasi yang dibutuhkan dengan benar, tidak berlebihan, sesuai dengan kejadian yang ada.Audience tentu saja memiliki makna dominan terhadap Tiktok, dimanaTiktok merupakan sumber informasi terkait perseteruan antara Dennis Chariesta dan Uya Kuya. Dalam hal ini, 
audiens akan menggunakan media sosial Tiktok sesuai dengan tujuan memperoleh informasi.

2. Negotiated Reading

Sejumlah orang menerima idealisme umum, tetapi dalam kasus-kasus tertentu dapat menolak untuk menerapkannya. Tingkat posisi negosiasi ketika menafsirkan video Tiktok bervariasi tergantung konteksnya. Informan 2 (angelica) menilai, Tiktok sebagai media untuk membantu masyarakat memberikan sebuah informasi yang mereka butuhkan dan dapat mereka ketahui. Namun di sisi lain, Informan 2 (Angelica) tidak setuju dengan informasi yang dikemas berlebihan di media sosial Tiktok. Dalam kasus Dennis Chariesta dan Uya Kuya, menurut Informan 2 (Angelica) dan media saat ini tidak dapat diandalkan, sehingga sebelum mendapatkan informasi, seseorang perlu mengetahui kebenaran informasi tersebut terlebih dahulu.

Menurut informan 1 (Sepia) dan 2 (Angelica), konten informasi yang berlebihan dapat berdampak negatif terhadap Dennis dan Uya sendiri. Informan yang dalam konteks ini merupakan dua mahasiswa. Kedua sumberini bergantung pada Tiktok dan terus-menerus mengamati Tiktok dalam kehidupan sehari-hari mereka, sehingga mereka dapat mengevaluasi lebih lanjut informasi dari media sosial Tiktok dan karenanya termasuk dalam kategori ini (Negotiated Reading). Mereka dapat mengembangkan makna dominan dari media, tergantung pada pengalaman, pengetahuan, dan budaya mereka. Oleh karena itu, sangat mungkin makna yang ditampilkan tidak selalu sesuai dengan makna yang diberikan oleh media.

3. Oppositional Reading

Pemaknaan khalayak pada posisi oposisi ini berupa menggantikan atau mengubah pesan atau kode dominan yang disampaikan media dengan pesan atau kode alternatif. Khalayak menolak makna dari pesan yang dimaksudkan atau disukai dan menggantikannya dengan cara berpikir mereka sendiritentang topik yang disampaikan oleh media. Informan membantah apa yang ditampilkan di media sosial Tiktok. Menurut informan 1 dan 2, jika berbicara tentang media sosial Tiktok, Tiktok kini terlihat sebagai media yang mencari ketenaran pengguna, bukan hanya media yang memberikan informasi dan hiburan kepada penggunanya.

\section{Simpulan}

Pemahaman millenial terhadap citra diri artis Denise Chariesta dan Uya Kuya yang ditampilkan di media sosial Tiktok dinilai negatif dan berlebihan. Kasus ini dipandang melalui dua sisi berbeda, antara kenyataan (perseteruan sungguhan) atau settingan semata. Millenial sebagai khalayak aktif mampu menciptakan pemahaman terhadap kasus perseteruan antara Denise Chariesta dan Uya Kuya di media lainya seperti Tiktok sesuai dengan latar belakang mereka masing-masing.

Pemaknaan millenial terhadap citra diri artis yang ditampilkan melalui media sosial Tiktok muncul dari beragam informasi tentang kasus perseteruan antara Denise Chariesta dan Uya Kuya di media sosialTiktok. Informan mengkode secara dominan karena menurut mereka informasi kasus perseteruan antara Denise Chariesta dan Uya Kuya di Tiktok merupakaninformasi yang berguna dan sesuai dengan kejadian yang ada, namun menolak sikap dan sifat yang ditunjukkan masing-masing artis pada konten Tiktok mereka yang lebih bersifat negatif karena mempertontonkan 
perseteruan pribadi di hadapan publik.

\section{Ucapan Terima Kasih}

Penulis menghanturkan banyak terima kasih kepada Fakultas Ilmu Komunikasi Universitas Tarumanagara. Ucapan terima kasih pula saya hanturkan kepada responden dan seluruh pihak yang telah memberikan dukungan dan bantuan dalam menyelesaikan penelitian ini.

\section{Daftar Pustaka}

Akhiri Perseteruan, Denise Chariesta Terharu Dibantu Keluarga Uya Kuya - Seleb Tempo.co. (n.d.). Retrieved July 17, 2021, from https://seleb.tempo.co/read/1484301/akhiri-perseteruan-denise-chariestaterharu-dibantu-keluarga-uya-kuya

Berapa Usia Mayoritas Pengguna Media Sosial di Indonesia?| Databoks. (n.d.). Retrieved February 19, 2020, from https://databoks.katadata.co.id/datapublish/2020/11/23/berapa-usiamayoritas-pengguna-media-sosial-di-indonesia

Bungin, Burhan. (2015). Metodologi Penelitian Kualitatif. Jakarta: Rajawali Pers

Hall, Stuart., Dorothy Hobson, Andrew Lowe and Paul Willis (Eds.). (1986). Culture, Media, Language. London: Hutchinson

Pattipeilohy, Esther Meilany. (2015). Citra Diri Dan Popularitas Artis. Jurnal Kajian Komunikasi. Volume 3, No. 1, Juni 2015

Sugiyono. (2014). Metode Penelitian Pendidikan Pendekatan Kuantitatif,. Kualitatif, dan R\&D. Bandung: Alfabeta 